\title{
Nodulation and Fixed Atmospheric Nitrogen of Some Local Lima Bean (Phaseolus lunatus L.) Cultivars Grown in a Coastal Savannah Environment
}

\author{
Daniel Kwasi Asare1,2, Christian Kofi Anthonio2, Lee Kheng Heng3, Emmanuel Ofori Ayeh1,2 \\ ${ }^{1}$ Nuclear Agriculture Research Institute, Ghana Atomic Energy Commission, Legon, Ghana \\ ${ }^{2}$ School of Nuclear and Allied Sciences, University of Ghana, Legon, Ghana \\ ${ }^{3}$ International Atomic Energy Agency, Vienna, Austria \\ Email: dank5000asare@gmail.com
}

Received 27 May 2015; accepted 12 September 2015; published 15 September 2015

Copyright (C) 2015 by authors and Scientific Research Publishing Inc.

This work is licensed under the Creative Commons Attribution International License (CC BY). http://creativecommons.org/licenses/by/4.0/

cC) (i) Open Access

\section{Abstract}

Legumes, in symbiotic association with Rhizobia, are able to fix atmospheric N. Six local lima bean (Phaseolus lunatus) cultivars were grown under rainfed conditions in a coastal savannah environment. Objectives of the study were to evaluate the nodulation and fixed atmospheric $\mathrm{N}$ levels of the six local lima bean cultivars using both the ${ }^{15} \mathrm{~N}$ isotope dilution method and $\mathrm{N}$ difference method (NDM). The linear relationship between fixed atmospheric $\mathrm{N}$ estimated using the ${ }^{15} \mathrm{~N}$ isotope dilution method and NDM, was also assessed. The experiment was arranged in a randomized complete block design (RCBD) in three replicates with seven treatments, comprising six lima bean cultivars (B1, B2, B3, B4, B5 and B6) and the early maturing local maize variety, "Doke", as the reference crop. Total, effective nodules (EN) and non-effective nodules (NEN) were determined on 42 and 56 days after planting (DAP). The ${ }^{15} \mathrm{~N}$ isotopic dilution method and NDM were used to quantify the fixed atmospheric $\mathrm{N}$ by the lima bean cultivars on $60 \mathrm{DAP}$. Effective root nodules per plant (EN) on 56 DAP ranged from 0.71 to 1.22, with the lima bean cultivar B4 having the highest value and cultivars B2 and B5 having the lowest value of EN, respectively. Similarly on 56 DAP, the lima bean cultivar B4 had the highest NEN value while cultivars B1, B2 and B5 had the lowest NEN value of 0.71 per plant. The mean fixed atmospheric $N$ was $8.98 \mathrm{~kg}^{2} \mathrm{ha}^{-1}$, based on the ${ }^{15} \mathrm{~N}$ isotope dilution method, which was lower than $10.13 \mathrm{~kg} \cdot \mathrm{ha}^{-1}$ of fixed atmospheric $\mathrm{N}$ determined using NDM. The linear relationship between fixed atmospheric $\mathrm{N}$ estimated using the ${ }^{15} \mathrm{~N}$ isotope dilution method and that estimated using the NDM, was positive but of average quality as the $\mathbf{R}^{2}$ value was 0.56. Consequently, the linear model obtained from this relationship is moderate as $56 \%$ of the data used for the linear regression analysis were accounted for by the linear regression model developed. However, NDM could be used for fast screening to select lima bean cultivars for a more 
detailed study to identify cultivars with promising fixed atmospheric $\mathrm{N}$ capabilities. Generally, results of the study provide opportunities for designing breeding and other agronomic programmes for enhancing the productivity and $\mathrm{N}$-fixing capacity of local lima beans in the coastal savannah environment.

\title{
Keywords
}

\author{
Lima Bean, Nodulation, Fixed Atmospheric Nitrogen, ${ }^{15} \mathrm{~N}$ Isotopic Dilution and N Difference \\ Methods
}

\section{Introduction}

Lima bean (Phaseolus lunatus L.) is a leguminous crop mostly grown on a marginal scale for human consumption [1] [2] and feeding ruminants [3]. Besides having the potential to fix atmospheric $\mathrm{N}$ and improve soil fertility under various cropping systems, lima bean is nutritious and has medicinal values [4]. Being the fourth in importance after cowpea, groundnut and bambara groundnut in Ghana [5], the production of lima bean is in the hands of peasant farmers who grow the crop in combination with plantain, cassava, cocoyam and vegetables [6] [7]. This low ranking of lima bean in importance, compared to other well-known grain legumes, is because this particular member of the Phaseolus species has not received the deserved research attention in Ghana [7].

Improving and maintaining soil fertility in cropping systems is crucial for enhancing sustainable rainfed food production in tropical environments. Legumes, including lima beans, can add organic matter to soils and consequently improve soil fertility and enhance stored moisture in the soil. Legumes, generally, fix atmospheric $\mathrm{N}$ by virtue of their symbiotic associations with soil rhizobia [8]. Although many natural ecosystems do not receive nitrogenous fertilizers, $\mathrm{N}$ balance studies have shown that soil $\mathrm{N}$ losses as a result of soil $\mathrm{N}$ uptake by crops, $\mathrm{N}$ leaching, erosion and nitrate- $\mathrm{N}$ denitrification are replenished to varying extents, by the process of biological nitrogen fixation [9].

The contribution of fixed atmospheric $\mathrm{N}$ is significant and important in cropping systems, especially in tropical environments. Fixed atmospheric $\mathrm{N}$ is not only inexpensive, compared to inorganic fertilizer $\mathrm{N}$, but it does not involve many of the disadvantages, including pollution hazards associated with non-judicious use of inorganic fertilizer N. Consequently, the full exploitation of biological nitrogen fixation is, therefore, necessary [9]. Objectives of this study, therefore, were to evaluate, in a coastal savannah environment, selected local lima bean cultivars for their ability to nodulate under field conditions and estimate their fixed atmospheric $\mathrm{N}$ using the ${ }^{15} \mathrm{~N}$ isotopic dilution and $\mathrm{N}$ difference methods. Additionally, the relationship between the amounts of fixed atmospheric $\mathrm{N}$ as determined by the ${ }^{15} \mathrm{~N}$ isotopic dilution method and that determined using the $\mathrm{N}$ difference method, was assessed. The overall objective of the study was to identify local lima bean cultivars that possess promising fixed atmospheric $\mathrm{N}$ qualities for incorporation into breeding programmes designed to enhance lima bean production and promote sustainable soil fertility in cropping systems in Ghana.

\section{Materials and Methods}

The research was conducted at the research farm of the Biotechnology and Nuclear Agriculture Research Institute (BNARI), Ghana Atomic Energy Commission (GAEC), from June, 2012 through to December, 2012 under rainfed conditions. The site is situated on latitude $05^{\circ} 40^{\prime} \mathrm{N}$ and longitude $0^{\circ} 13^{\prime} \mathrm{W}$ in the coastal savannah environment of Ghana. The site has an altitude of $76 \mathrm{~m}$ above sea level and located $20 \mathrm{~km}$ north of Accra (Ghana). The annual rainfall at the site ranges between 700 and $1000 \mathrm{~mm}$ [10]. The soil is a well-drained savannah ochrosol (Ferric Acrisol), locally called Haatso series (sandy loam), which is derived from quartzite schist [11]. Some of the chemical and physical characteristics of the soil are listed in Table 1.

The experiment was arranged in a randomized complete block design (RCBD) with seven treatments (six lima bean cultivars and an early maturing maize variety "Doke" used as a reference crop) in three replications. The local lima bean cultivars used were B1, B2, B3, B4, B5 and B6. The six lima bean cultivars were planted on the $13^{\text {th }}$ day of June, 2012, at a planting distance of $1.6 \mathrm{~m}$ between rows and $1.0 \mathrm{~m}$ within rows with two seeds per hill, giving a total of 96 stands per sub-plot. The reference maize crop was also sown in each sub-plot using the 
Table 1. Some of the physical and chemical properties of the soil at the experimental site.

\begin{tabular}{cc}
\hline Soil property & Value \\
\hline $\mathrm{pH}\left(\mathrm{H}_{2} \mathrm{O}\right)(1: 2)$ & 7.8 \\
Org. C./Org. matter (\%) & $1.83 / 3.2$ \\
$\mathrm{NH}_{4} \mathrm{~N}(\mathrm{mg} / \mathrm{Kg} / \mu \mathrm{g} / \mathrm{g})$ & $56(0.0224 \% \mathrm{~N})$ \\
$\mathrm{NO}_{3} \mathrm{~N}(\mathrm{mg} / \mathrm{Kg} / \mu \mathrm{g} / \mathrm{g})$ & $476(0.1904 \% \mathrm{~N})$ \\
$\mathrm{P}(\mathrm{mg} / \mathrm{Kg} / \mu \mathrm{g} / \mathrm{g})$ & 84 \\
$\mathrm{~K}(\mathrm{cmol} / \mathrm{Kg} / \mathrm{me} / 100 \mathrm{~g})$ & 4.35 \\
$\mathrm{Sand}(\%)$ & 41.41 \\
Silt (\%) & 43.17 \\
Clay (\%) & 15.42 \\
Textural class & sandy loam \\
\hline
\end{tabular}

same planting distance on the day lima bean cultivars were sown. The total size of the plot measured $48.0 \mathrm{~m} \times$ $39.6 \mathrm{~m}$, giving a total area of $1900.8 \mathrm{~m}^{2}$.

A micro plot, measuring $4 \mathrm{~m} \times 3.2 \mathrm{~m}\left(12.8 \mathrm{~m}^{2}\right)$, was established in each subplot. A total of $20 \mathrm{~kg} \mathrm{~N} \mathrm{ha}^{-1}$ of ${ }^{15} \mathrm{~N}$-labelled urea $\left(\mathrm{CO}\left(\mathrm{NH}_{2}\right)_{2}\right)$, having 2.286 atom $\%{ }^{15} \mathrm{~N}$, was applied in a solution form to the test plants in each micro plot 31 days after planting (DAP). Plants outside the micro plot also received $20 \mathrm{~kg} \mathrm{~N} \mathrm{ha}^{-1}$ of ordinary urea. The fertilizer was applied by the method of ringing into a shallow groove which was equidistant from each plant. Potassium (K) and phosphorus (P) fertilizers were not applied since the soil analysis indicated that these elements were in adequate amounts (Table 1) to satisfy the growth requirement of the crops. However, a broad spectrum insecticide, Pyrinex 48 EC (O, O-Diethyl 0-3, 5, 6-trichloro-2-pyridylphosphorothionate) was applied at the rate of $2 \mathrm{ml} \cdot \mathrm{L}^{-1}$ to the whole field 16 and 30 DAP. Weeding was done manually whenever necessary. Creeping lima bean plants were staked.

Total nodules for each lima bean plant were countered and those with size less than $2 \mathrm{~mm}$ were classified as non-effective while those with size above $2 \mathrm{~mm}$ were classified as effective [12]. For confirmation, sliced nodules which showed reddish or pinkish colour, indicating nitrogen fixation has commenced, were labelled as effective while sliced nodules which appeared white or grey were also classified as immature and non-effective in fixing atmospheric $N$ [13]. Samples for nodule count and classification were taken at 42 and 56 DAP for the atmospheric $\mathrm{N}$ fixing lima beans.

Lima beans and reference maize crops were sampled from ${ }^{15} \mathrm{~N}$ micro plots 60 days after the ${ }^{15} \mathrm{~N}$-labeled fertilizer application. Sub-samples of plants taken from ${ }^{15} \mathrm{~N}$ micro plots were oven dried at $70^{\circ} \mathrm{C}$ to a constant weight, ground to pass through a 1-mm screen mesh, and then sub-samples analysed for ${ }^{15} \mathrm{~N}$ and $\mathrm{N}$ contents at the Laboratory of the International Atomic Energy Agency located at Seiberdorf, Austria. The above-ground biomass for lima beans cultivars and maize reference crop, sampled from the ${ }^{15} \mathrm{~N}$ micro plots, were used to estimate fixed atmospheric $\mathrm{N}$ for the lima bean cultivars, using their $\mathrm{N}$ and ${ }^{15} \mathrm{~N}$ contents.

\subsection{Estimation of Fixed Atmospheric $\mathbf{N}$}

Both the ${ }^{15} \mathrm{~N}$ isotopic dilution and $\mathrm{N}$ difference methods were used to estimate fixed atmospheric $\mathrm{N}$ for the six lima bean cultivars.

\section{2. ${ }^{15} \mathrm{~N}$ Isotopic Dilution Method}

The ${ }^{15} \mathrm{~N}$ Isotopic dilution method, as given by the International Atomic Energy Agency, Vienna, Austria [14], was used to estimate fixed atmospheric $\mathrm{N}$ of the six lima bean cultivars. The methodology is outlined below:

$$
\% \mathrm{NdfA}_{\mathrm{F}}=\left(1-\frac{\text { atom } \% \mathrm{~N}-15 \text { excess in fixing plant }}{\text { atom } \% \mathrm{~N}-15 \text { excess in reference plant }}\right) \times 100
$$

where $\% \mathrm{NdfA}_{\mathrm{F}}$ is the percent $\mathrm{N}$ derived from the atmosphere by the $\mathrm{N}$ fixing plant and $\%{ }^{15} \mathrm{~N}$ excess is a measure of a sample's ${ }^{15} \mathrm{~N}$ content above the natural abundance of $\mathrm{N}$ in biological samples $(0.366 \%)$.

Therefore, the amount of atmospheric $\mathrm{N}$ fixed by lima bean crops (ANF) was estimated as: 


$$
\mathrm{ANF}=\mathrm{TNF} \times \frac{\% \mathrm{NdfA}_{\mathrm{F}}}{100}
$$

where TNF is the total $\mathrm{N}\left(\mathrm{kg} \cdot \mathrm{ha}^{-1}\right)$ in the fixing crop. The TNF $\left(\mathrm{kg} \cdot \mathrm{ha}^{-1}\right)$ was computed as:

$$
\mathrm{TNF}=\mathrm{TDM} \times \% \mathrm{~N} / 100
$$

where TDM is the total above ground dry biomass $\left(\mathrm{kg} \mathrm{ha}^{-1}\right)$ and $\% \mathrm{~N}$ is the $\mathrm{N}$ content in the above ground dry biomass in percent.

\subsection{Nitrogen (N) Difference Method}

The nitrogen difference method (NDM) is simple and has been used by several workers, including Broadbent et $a l$. [15] and Legg and Sloger [16], to estimate fixed atmospheric $\mathrm{N}$ by legumes. Assumptions behind the method are that the fixing lima bean and non-fixing reference maize crops take up similar amounts of soil $\mathrm{N}$ and applied fertiliser $\mathrm{N}$ and that legume crops have atmospheric $\mathrm{N}$ as an additional source of $\mathrm{N}$ for their use. Consequently,

$$
\operatorname{ANF}\left(\mathrm{kg} \cdot \mathrm{ha}^{-1}\right)=\mathrm{TNY}_{\mathrm{f}}-\mathrm{TNY}_{\mathrm{nf}}
$$

where $\mathrm{TNY}_{\mathrm{f}}\left(\mathrm{kg} \cdot \mathrm{ha}^{-1}\right)$ and $\mathrm{TNY}_{\mathrm{nf}}\left(\mathrm{kg} \cdot \mathrm{ha}^{-1}\right)$ are the total $\mathrm{N}$ yield (total $\mathrm{N}$ ) of the fixing crop and non-fixing crop, respectively, and ANF is the atmospheric $\mathrm{N}$ fixed by the legume crop.

\section{Results}

The mean number of root nodules per plant for the six cultivars of the lima bean ranged between 1.0 and 3.39 on 42 DAP (Figure 1(a)). The lima bean cultivar B3 had the highest number of root nodules (3.39) followed by cultivar B4 (2.78), but this difference was not significant $(\mathrm{P} \geq 0.05)$. The rest of the lima bean cultivars produced very low root nodule numbers on $42 \mathrm{DAP}$, ranging from 1.0 to 1.39 per, which were also not significantly different $(P \geq 0.05)$ from each other. Lima bean cultivars B3 and B4 had similar number of root nodules which was, however, significantly different $(\mathrm{P} \leq 0.05)$ from root nodule numbers produced by other lima bean cultivars.

There was a general reduction in the mean number of root nodules per plant as lima beans matured from 42 DAP to 56 DAP. Specifically, the mean number of root nodules produced on 56 DAP dropped drastically compared to those observed on $42 \mathrm{DAP}$ and ranged from 0.71 to 1.95 per plant (Figure 1(b)). There was also a very steep drop in the mean number of nodules produced by the lima bean cultivar B5 which produced 1.79 nodules per plant on 42 DAP but only 0.71 nodules per plant on 56 DAP. The drop in the mean number of root nodules per plant from 42 DAP to 56 DAP observed in the lima bean cultivar B6, however, was marginal (1.39 on 42 DAP to 1.06 on $56 \mathrm{DAP})$. In contrast, the lima bean B4 produced the highest mean nodule number of 1.95 per plant on 56 DAP which was significantly higher $(\mathrm{P} \leq 0.05)$ than those of other Lima bean cultivars (Figure $1(\mathrm{~b})$ ).

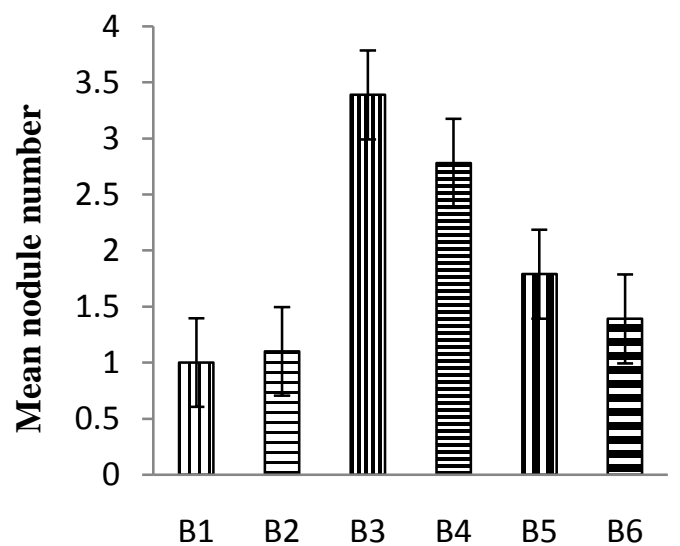

Lima bean cultivar

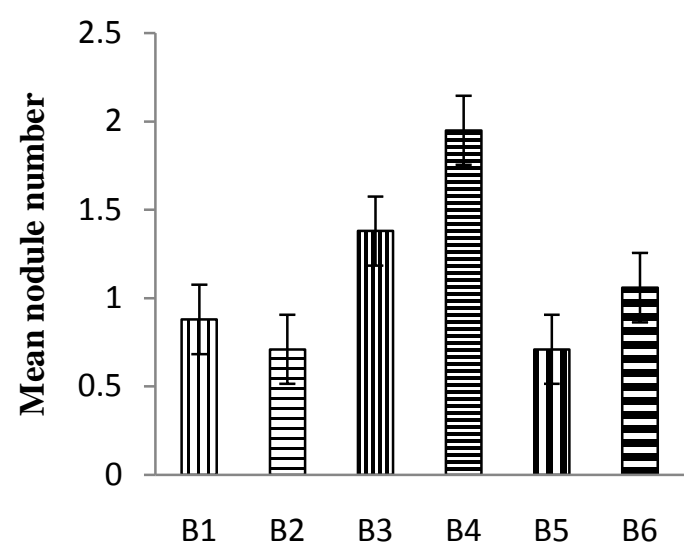

Lima bean cultivar

(b)

Figure 1. Mean root nodule number per plant on (a) 42 and (b) 56 DAP. Each error bar represents plus or minus one standard deviation. 
The lima bean cultivar B3 followed closely, producing a mean number of 1.38 root nodules per plant on 56 DAP. The rest of the lima bean cultivars, however, did not significantly differ $(\mathrm{P} \leq 0.05)$ in the mean number of nodules per plant on 56 DAP.

The mean effective nodule numbers (ENN) per plant on 42 DAP for all the six lima bean cultivars ranged from 0.71 to 1.43. The lima bean cultivar B4 had the highest ENN of 1.43, followed closely by that of cultivar B6, which had ENN of 1.18 and then cultivar B3 with ENN of 1.00. The rest of the lima bean cultivars had ENN that ranged from 0.71 to 0.88 on 42 DAP (Figure 2).

In contrast, the mean number of non-effective root nodules (NEN) observed on 42 DAP for the six lima bean cultivars ranged from 0.88 to 3.33 (Figure 2) with the lima bean cultivar B3 produced the highest NEN of 3.33, while the cultivar B1 produced the lowest NEN of 0.88. The lima bean cultivar B4 had 2.51 NEN followed by cultivar B5 with 1.79 NEN (Figure 2).

On 56 DAP, however, ENN ranged between 0.71 and 1.22 among the lima bean cultivars (Figure 2). While each of the lima bean cultivars B2 and B5 had ENN of 0.71, cultivar B4 had the highest ENN of 1.22, while with cultivars B3 and B6 produced ENN of 1.00 (Figure 2). Thus, the trend in the mean number of NEN changed slightly on 56 DAP as the lima cultivar B4 produced the maximum NEN of 1.43, followed by cultivars B6 and B3 with NEN value of 1.39 and 1.35, respectively (Figure 2). However, lima bean cultivars B1, B2 and B5 produced similar NEN of 0.71 each on 56 DAP (Figure 2).

The percent fixed atmospheric N (PFAN) ranged from 39.8\% to 81.0\% with Lima cultivars B1 and B6 having the lowest and highest PFAN value, respectively (Figure 3(a)). Lima bean cultivars B1 and B2 had similar

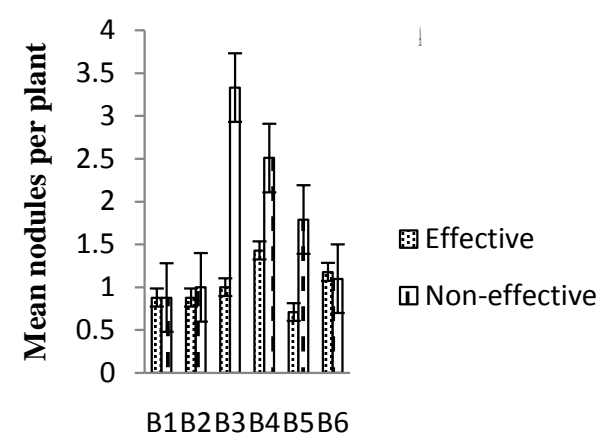

Lima bean cultivar

(a)

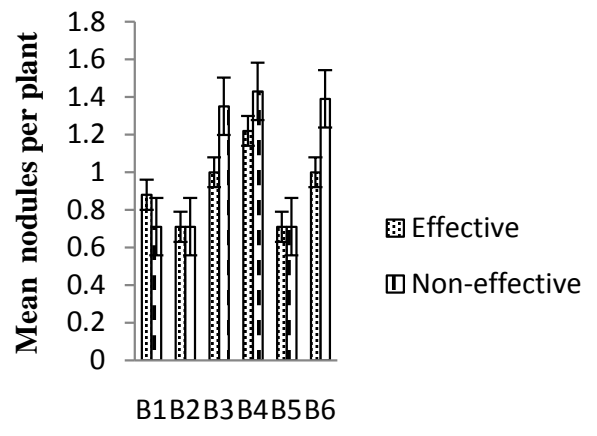

Lima bean cultivar

(b)

Figure 2. Mean effective and non-effective nodule numbers per plant on (a) 42 and (b) 56 DAP for six lima bean cultivars. Each error bar represents plus or minus one standard deviation.

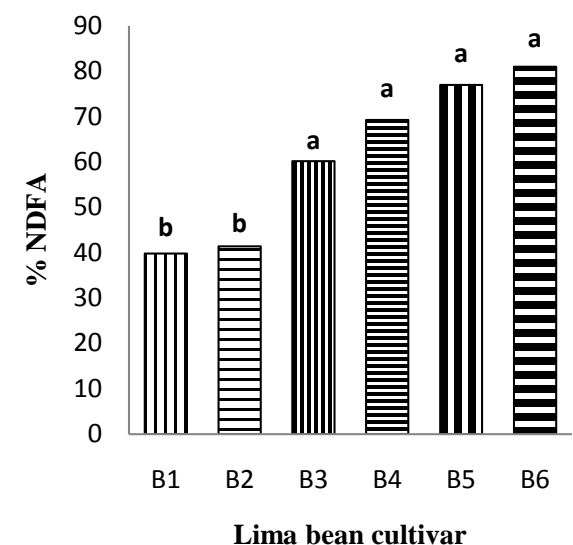

(a)

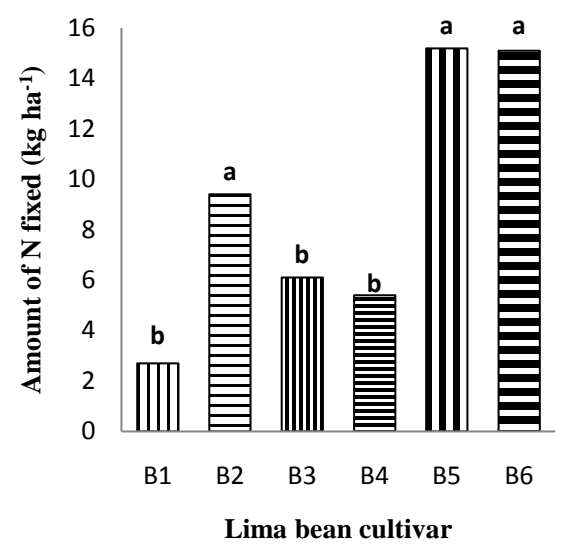

(b)

Figure 3. (a) Percent fixed atmospheric $\mathrm{N}$ and (b) total amount of fixed atmospheric $\mathrm{N}$ by six lima bean cultivars as estimated by the ${ }^{15} \mathrm{~N}$ isotopic dilution method. Bars with the same letters are not significantly different $(\mathrm{P}>0.05)$. 
PFAN values $(P \geq 0.05)$ which are significantly different $(P \leq 0.05)$ from PFAN values for cultivars B3, B4, B5 and B6 (Figure 3(a)). Additionally, PFAN ranged from $2.70 \mathrm{~kg} \cdot \mathrm{ha}^{-1}$ to $15.2 \mathrm{~kg} \cdot \mathrm{ha}^{-1}$, while the lima bean cultivars B1 and B6 produced the lowest and highest PFAN values, respectively. Furthermore, ANF values differed significantly $(\mathrm{P} \leq 0.05)$ among lima bean cultivars. However, lima bean cultivars B5, B6 and B2 fixed similar amounts of atmospheric $\mathrm{N}(\mathrm{P} \geq 0.05)$ of $15.2 \mathrm{~kg} \cdot \mathrm{ha}^{-1}, 15.1 \mathrm{~kg} \cdot \mathrm{ha}^{-1}, 9.4 \mathrm{~kg} \cdot \mathrm{ha}^{-1}$, respectively. Also, lima bean cultivars $\mathrm{B} 1, \mathrm{~B} 3$ and $\mathrm{B} 4$ fixed similar amounts of atmospheric $\mathrm{N}(\mathrm{P} \geq 0.05)$ which were significantly different $(\mathrm{P} \leq 0.05)$ from fixed atmospheric $\mathrm{N}$ fixed by cultivars B5, B6 and B2 (Figure 3(b)).

On the other hand, the total atmospheric $\mathrm{N}$ fixed by the lima bean cultivars as determined by the $\mathrm{N}$ difference method (NDM), ranged from $3.5 \mathrm{~kg} \cdot \mathrm{ha}^{-1}$ and $19.3 \mathrm{~kg} \cdot \mathrm{ha}^{-1}$. Per NDM, the lima bean cultivar B2 fixed the highest $\mathrm{N}$ whereas the lowest $\mathrm{N}$ was fixed by the cultivar $\mathrm{B} 4$. A significant difference $(\mathrm{P} \leq 0.05)$ was observed in fixed $\mathrm{N}$, based on NDM, by the lima bean cultivars with cultivars B1, B3 and B4 fixing similar levels of $\mathrm{N}$ which were statistically $(\mathrm{P} \leq 0.05)$ lower than the fixed atmospheric $\mathrm{N}$ by cultivars B2, B5 and B6 (Figure 4).

\section{Discussion}

Legumes generally form the maximum number of root nodules on 42 DAP [17]. The range $1.00-3.40$ of total root nodule number per plant among the lima bean cultivars observed in our study agreed with 1.00 - 2.00 reported by Ibeawuchi et al. [17] for some lima beans intercropped with maize, yam, cassava and African yam bean.

The range, 0.70 - 2.00, of root nodules per plant produced by the lima bean cultivars on 56 DAP (at the onset of flowering), was at variance with that of Chemining'wa et al. [18], who reported a mean nodule number of 1.4 per plant for the lima bean at its flowering stage. Thus, the lima bean cultivars produced lower nodule numbers per plant in the coastal savannah environment where our study was conducted. This disparity in nodule numbers might have been due to differences in experimental conditions and cultural practices Danso and Eskew [19].

Additionally, the reduction in nodule numbers per plant observed from 42 DAP to 56 DAP suggests that during the flowering (reproductive) stage, lima bean plants supply more energy and nutrients to plant parts than for nodules formulation. This is because legumes do not produce unlimited amount of sugar for plant use [13] [20]. Furthermore, nodules deteriorated in response to severe weather conditions such as high temperatures and erratic rainfall experienced during the latter stages of our field experiment. Specifically, a total of $290.7 \mathrm{~mm}$ rainfall was recorded during the entire period of the experiment (June-December) during the year 2012. This $290.7 \mathrm{~mm}$ of rainfall is below the recommended rainfall of $900-1500 \mathrm{~mm}$, though lima bean can tolerate as low as 500 $600 \mathrm{~mm}$ rains per annum [21]. Also, an average maximum air temperature of $31.9^{\circ} \mathrm{C}$ and a minimum air temperature of $23.5^{\circ} \mathrm{C}$ were recorded during the field experiment as against the temperature range of $16^{\circ} \mathrm{C}-27^{\circ} \mathrm{C}$

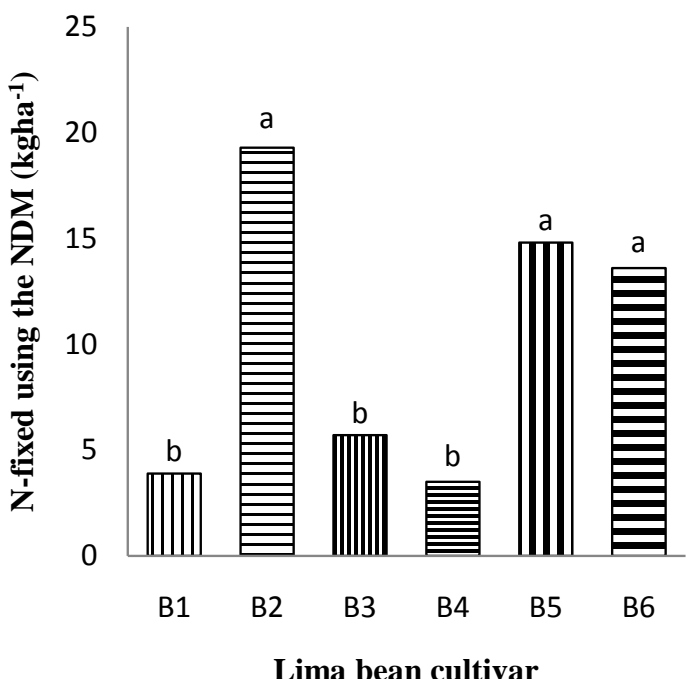

Figure 4. Fixed atmospheric $\mathrm{N}$ by six lima bean cultivars as determined by the $\mathrm{N}$ difference method. Bars with the same letters are not significantly different $(\mathrm{P}>0.05)$. 
recommended by Ibeawuchi et al. [21] for optimal growth of lima beans. Thus, the high temperatures experienced at the experimental site could also be detrimental to nodule formation because the process is purely enzymatic and enzymes function best in narrow and specific limited temperature ranges [22].

The number of ENN produced should positively correlate with the amount of $\mathrm{N}$ fixed by the lima beans. Studies have, however, shown that many legumes are capable of stimulating $\mathrm{N}$ fixation by free-living bacteria which live in their rhizospheres, without entering into symbiotic relationship with the plant [23], which is an associative nitrogen fixation process [17]. The suggestion is that the lima bean cultivars which recorded less root nodules might have also been involved in associative nitrogen fixation, resulting in the observed higher amounts of fixed atmospheric N. Thus, high number of effective root nodules would not necessarily culminate in high nitrogen fixation and that rhizobia that fix high levels of atmospheric $\mathrm{N}$ when in symbiotic association with legumes would not necessarily be those that form the most nodules. Conversely, it is likely to find nodules formed on leguminous plants by rhizobia that are ineffective at fixing atmospheric N. In soils where there are different strains of rhizobia that nodulate the same legume species, many factors influence the success or failure of nodulation. Therefore, the full potential for atmospheric $\mathrm{N}$ fixation by legumes is not always achieved, even if highly effective strains of rhizobia are present in the soil [24] and have succeeded to infect roots of legume species.

Lima bean cultivars B6, B5 and B4 had the highest percentages of $81 \%, 77 \%$ and $69.3 \% \mathrm{~N}$, respectively, derived from the atmospheric $\mathrm{N}$ whereas lima bean cultivars B3, B2 and B1 had the least percent of $60.2 \%, 41.4 \%$ and $39.8 \%$, respectively, of fixed atmospheric $\mathrm{N}$ based on ${ }^{15} \mathrm{~N}$ dilution method. This trend is the exact opposite of the percent $\mathrm{N}$ derived from the ${ }^{15} \mathrm{~N}$ labelled fertilizer. Generally, the higher the percent of fixed atmospheric $\mathrm{N}$, the higher the $\mathrm{N}$ fixation by legumes and vice versa. This phenomenon culminated from the low atom $\%{ }^{15} \mathrm{~N}$ excess observed in the lima bean cultivars. This is in agreement with Kagabo [24], who reported that the dilution of $\mathrm{N}$ isotope ratios in the $\mathrm{N}$-fixing peanut and soybean plants was due to an $\mathrm{N}$ source of significantly lower ${ }^{15} \mathrm{~N}$ content in the atmosphere.

Lima bean cultivars B5, B6 and B2 were the highest $\mathrm{N}$ fixers with total amount of $15.2 \mathrm{~kg} \mathrm{~N} \mathrm{ha}^{-1}, 15.1 \mathrm{~kg} \mathrm{~N}$ $\mathrm{ha}^{-1}$ and $9.4 \mathrm{~kg} \mathrm{~N} \mathrm{ha}^{-1}$, respectively. However, very low amounts of atmospheric $\mathrm{N}$ were fixed by B3 $(6.1 \mathrm{~kg} \mathrm{~N}$ $\left.\mathrm{ha}^{-1}\right)$, B4 $\left(5.4 \mathrm{~kg} \mathrm{~N} \mathrm{ha}^{-1}\right)$ and B1 $\left(2.7 \mathrm{~kg} \mathrm{~N} \mathrm{ha}^{-1}\right)$. Soil analysis for total $\mathrm{N}$ revealed $0.0224 \% \mathrm{~N}^{-} \mathrm{NH}_{4}-\mathrm{N}_{\text {and }}$ $0.1904 \% \mathrm{~N}$ for $\mathrm{NO}_{3}-\mathrm{N}$, an indication that the soil has low level of total $\mathrm{N}$ (Table 1). This low level of total $\mathrm{N}$ in the soil likely enhanced the fixed atmospheric $\mathrm{N}$ by the lima bean crops.

The amounts of atmospheric $\mathrm{N}$ used by the lima bean cultivars were between $3.5 \mathrm{~kg} \cdot \mathrm{ha}^{-1}$ and $19.3 \mathrm{~kg} \cdot \mathrm{ha}^{-1}$, based on the $\mathrm{N}$ difference method. Lima bean cultivars B1 and B2, however, had comparatively higher levels of fixed atmospheric $\mathrm{N}$ based on the $\mathrm{N}$ difference method compared to the ${ }^{15} \mathrm{~N}$ isotope dilution method. The precision of the $\mathrm{N}$ difference method is strongly influenced by how close the estimate of soil $\mathrm{N}$ uptake by the reference crop is to that taken up by the $\mathrm{N}$-fixing legume [15] [16]. This observation was made for the lima bean cultivar B1 which accumulated a total of $8.80 \mathrm{~kg} \mathrm{~N} \mathrm{ha}^{-1}$ and $24.1 \mathrm{~kg} \mathrm{~N} \mathrm{ha}^{-1}$ for cultivar B2 as against an average of $4.40 \mathrm{~kg} \mathrm{~N} \mathrm{ha}^{-1}$ of total $\mathrm{N}$ accumulated by the maize reference crop used for the study, indicating that these lima bean cultivars were highest in fixing atmospheric N. Several reports, including those by [15] [16] have, however, showed a high correlation between fixed atmospheric determined using NDM and those by other methods, including the ${ }^{15} \mathrm{~N}$ isotope dilution method. These reports, however, were at variance with our results as fixed atmospheric $\mathrm{N}$ estimated using the ${ }^{15} \mathrm{~N}$ isotope dilution method positively, linearly but averagely related $\left(\mathrm{R}^{2}=\right.$ 0.56 ) to the fixed atmospheric $\mathrm{N}$ estimated using the NDM. Differences in the amount of atmospheric $\mathrm{N}$ fixed by the lima bean cultivars, determined using NDM and ${ }^{15} \mathrm{~N}$ isotopic dilution method, was due to differences in the accuracy of the two methodologies used [25].

Additionally, the linear regression between ENN and total amount of fixed atmospheric $\mathrm{N}$, as determined by the ${ }^{15} \mathrm{~N}$ isotope dilution method, resulted in a positive relationship with $\mathrm{R}^{2}$ value of 0.76 . As effective root nodules are those carrying out the atmospheric $\mathrm{N}$ fixation, it is expected that the presence of high NEN would translate into high amount of fixed atmospheric N. However, for the fixed atmospheric N as determined using NDM, a negative and weak linear relationship resulted with $\mathrm{R}^{2}$ value of 0.21 . This could be that some of the lima bean cultivars derived most of their $\mathrm{N}$ from the soil and ${ }^{15} \mathrm{~N}$-labeled fertilizer. Our results showed that lima bean cultivars B1 and B2 derived the bulk of their total accumulated $\mathrm{N}$ from the native soil (Table 2), which likely explains the comparatively lower fixed atmospheric $\mathrm{N}$ estimated using NDM compared to that estimated using the ${ }^{15} \mathrm{~N}$ isotope dilution method. Furthermore, the presence of ENN would not necessarily translate into fixed atmospheric $\mathrm{N}$ as many factors could affect the $\mathrm{N}$-fixation capacity of effective nodules. According to Christie and Hanson [23], strains of rhizobia involved in the nodulation process, nutritional status of the legume crop and soil 
Table 2. Total nitrogen derived from three sources by six lima bean cultivars at $60 \mathrm{DAP}$ based on the ${ }^{15} \mathrm{~N}$ dilution methodology.

\begin{tabular}{ccccc|}
\hline & \multicolumn{3}{c}{ Lima bean } \\
\hline cultivar & Total N-yield & Fertilizer N-yield & N-fixed & Soil N \\
\hline B1 & 8.80 & 0.658 & 2.70 & 5.45 \\
B2 & 24.12 & 1.570 & 9.40 & 13.20 \\
B3 & 10.52 & 0.595 & 6.10 & 3.83 \\
B4 & 8.32 & 0.310 & 5.40 & 2.64 \\
B5 & 19.68 & 0.626 & 15.20 & 3.83 \\
B6 & 18.44 & 0.566 & 15.10 & 2.80 \\
\hline
\end{tabular}

moisture conditions are some of the factors that could determine the amount of fixed atmospheric $\mathrm{N}$ [26].

\section{Conclusion}

Lima bean cultivars B3 and B4 produced the highest number of root nodules, ENN and NEN. Furthermore, lima bean cultivars B2, B5 and B6 were comparatively the highest fixers of atmospheric $\mathrm{N}$ compared to lima bean cultivars B1 and B3 and B4, regardless of the method used to estimate fixed atmospheric N. The quality of the linear relationship that existed between fixed atmospheric $\mathrm{N}$ of the six lima bean crops, estimated using both the ${ }^{15} \mathrm{~N}$ isotope dilution method and NDM, suggested that the model might not be able to select all the local lima bean cultivars, after screening, with promising fixed atmospheric $\mathrm{N}$ capabilities for detailed study.

\section{Acknowledgements}

The authors acknowledge with thanks the assistance of the International Atomic Energy Agency, Austria, for analysing plant samples for their ${ }^{15} \mathrm{~N}$ and total $\mathrm{N}$ contents.

\section{References}

[1] Broughton, W.J., Hernández, G., Blair, M., Beebe, S., Gepts, P. and Vanderleyden, J. (2002) LBMPS, Université de Genve, ch. de l'Impératrice, 1292 Chambèsy, Genève, Switzerland. CIFN, UNAM, Cuernavaca, Mexico. CIAT, Cali, Colombia. University of California, Davis, USA. CMPG, Katholieke Universiteit, Heverlee, Belgium.

[2] Sauvant, D., Heuzé, V., Tran, G., Bastianelli, D. and Lebas, F. (2015) Lima beans (Phaseolus lunatus). Feedipedia, a programme by INRA, CIRAD, AFZ and FAO. http://www.feedipedia.org/node/267

[3] Ajayi, F.T., Akande, S.R., Adegbite, A.A. and Idowu, B. (2009) Assessment of Seven Under-Utilized Grain Legume Foliages as Feed Sources for Ruminants. Livestock Research for Rural Development, 21. http://www.lrrd.org/lrrd21/9/ajay21149.htm

[4] Akande, S.R. and Balogun, M.O. (2007) Evaluation and Heritability Studies of Local Lima Bean (Phaseolus lunatus L.) Cultivars from Southwest Nigeria. Institute of Agricultural Research and Training Obafemi Awolowo University, Moor Plantation, P.M.B. 5029, Ibadan, Nigeria, 22-28.

[5] Doku, E.V. (1977) Grain Legume Production in Ghana. In: Doku, E.V., Ed., Proceedings of the Joint University of Ghana Council for Scientific and Industrial Research Symposium on Grain Legumes in Ghana, The Institute of Adult Education, University of Ghana, Legon, 1-7.

[6] Ibeawuchi, I.I. and Ofoh, M.C. (2000) Productivity of Maize/Cassava/Food Legume Mixtures in South Eastern Nigeria. Journal of Agriculture \& Rural Development, 1, 1-9. http://www.sciencepub.org/newyork

[7] Aboagye, L.M., Owusu, S.K. and Badger, N.G. (2007) Evaluation of Some Lima (Phaseolus lunatus) Germplasm Collected from Ghana. Ghana Journal of Horticulture, 6, 17-22.

[8] Belk, C. and Borden, V. (2007) Biology: Science for Life with Physiology. 2nd Edition, Pearson Prentice Hall, Inc., Upper Saddle River, 590-591.

[9] Hardarson, G., Zapata, F. and Danso, K.S.A. (1987) Effect of Plant Genotype and Nitrogen Fertilizer on Symbiotic Nitrogen Fixation by Soybean Cultivars. Plant and Soil, 82, 397-405. http://dx.doi.org/10.1007/BF02184277

[10] Morris, M.L., Tripp, R. and Dankyi, A.A. (1999) Adoption and Impacts of Improvedmaize Production Technology: A Case Study of the Ghana Grains Development Project. Economics Program Paper 99-01, CIMMYT, Mexico D.F., 
3-41.

[11] FAO/UNESCO (1994) Soil Map of the World, Revised Legend. World Resources Report 60, FAO, Rome, 146.

[12] Schulz, S., Engel, M., Fischer, D., Buegger, F., Elmer, M., Welzl, G. and Schloter, M. (2012) Diversity Pattern of Nitrogen Fixing Microbes in Nodules of Trifolium arvense (L.) at Different Initial Stages of Ecosystem Development. Biogeosciences, 10, 1183-1192.

[13] Lindemann, W.C. and Glover, C.R. (2003) Guide A-129. Cooperative Extension Service, College of Agriculture and Home Economics, New Mexico State University, Las Cruces, 1-3.

[14] IAEA (2001) Use of Isotope and Radiation Methods in Soils and Water Management and Crop Nutrition. Training Course Series 14, Vienna, 1-247.

[15] Broadbent, F.E., Nakashima, T. and Chang, G.Y. (1982) Estimation of Nitrogen Fixation by Isotope Dilution in Field and Greenhouse Experiments. Agronomy Journal, 74, 625-628. http://dx.doi.org/10.2134/agronj1982.00021962007400040009x

[16] Legg, J.O. and Sloger, C. (1975) A Tracer Method for Determining Nitrogen Fixation in Field Studies. In: Klein, E.R. and Klein, P.D., Eds., Proceedings of the 2nd International Conference on Stable Isotopes, US Energy Research and Development Administration, Washington DC, 661-666.

[17] Ibeawuchi, I.I., Obiefuna, J.C., Nwufo, M.I. and Ofoh, M.C. (2007) Nodulation and Nitrogen Fixation by Landrace Legumes in Yam/Cassava Based Cropping Systems of the Tropical Rainforest. Department of Crop Science and Technology Federal University of Technology Owerri, Nigeria. New York Science Journal, 1, 1-12. http://www.sciencepub.org/newyork

[18] Chemining’wa, G.N., Theuri, S.W.M. and Muthomi, J.W. (2004) Effect of Rhizobia Inoculation and Starter-N on Nodulation and Yield of Grain Legumes. Department of Plant Science and Crop Protection, Faculty of Agriculture, University of Nairobi, Nairobi.

[19] Ibeawuchi, I.I. (2007) Landrace Legumes: Synopsis of the Culture, Importance, Potentials and Roles in Agricultural Production Systems. Journal of Biological Sciences, 7, 464-474. http://dx.doi.org/10.3923/jbs.2007.464.474

[20] Dano, S.K.A. and Eskew, D.L. (1984) Enhancing Biological Nitrogen Fixation. IAEA Bulletin, 26, 29-30.

[21] Ibeawuchi, I.I., Obiefina, J.C., Ofoh, M.C., Ihejirika, G.O., Tom, C.T., Owneremadu, E.U. and Opara, C.C. (2004) An Evaluation of Four Soyabean Varieties Intercropped with Okro in Owerri Ultisol of South Eastern Nigeria. Pakistan Journal of Biological Sciences (PJBS), 8, 215-219.

[22] Peoples, M.B., Faizah, A.W., Rerkasem, B. and Herridge, D.F. (1989) Methods for Evaluating Biological Nitrogen Fixation by Nodulated Legumes in the Field. No. 11, Australian Centre for International Agricultural Research, Canberra, vii $+76 \mathrm{p}$.

[23] Christie, B.R. and Hanson, A.A. (1987) CRC Handbook of Plant Science in Agriculture. CRC Press, Boca Raton, 165-169.

[24] Kagabo, W.E. (1986) Nitrogen Fixation in Field-Grown Legumes Measured by the 15N Isotope Dilution and the Difference Methods. Master's Thesis, Graduate Division of the University of Hawaii, Honolulu, 21.

[25] www.cilr.uq.edu.au

[26] Sellstedt, A., Staahl, L., Mattsson, M., Jonsson, K. and Hoegberg, P. (1993) Can the ${ }^{15}$ N Dilution Technique Be Used to Study $\mathrm{N}_{2}$ Fixation in Tropical Tree Symbioses as Affected by Water Deficit? Journal of Experimental Botany, 44, 1749-1755. http://dx.doi.org/10.1093/jxb/44.12.1749 